\title{
Impact of heat stress on milk yield and composition in early lactation of
} Holstein Friesian crossbred cattle

\author{
T Chanda' ${ }^{1}$, GK Debnath ${ }^{2 *}$, KI Khan², MM Rahman ${ }^{3}$ and GC Chanda ${ }^{2}$
}

Affiliation: ${ }^{1}$ Associate Professor, Patuakhali Science and Technology University (PSTU), ${ }^{2}$ Professor, Chittagong Veterinary and Animal Sciences University (CVASU), ${ }^{3}$ Professor, Bangabandhu Sheikh Mujibur Rahman Agricultural University, Gazipur, Bangladesh

\begin{abstract}
The aim of the study was to know the effect of heat stress on milk yield and its composition of Holstein Friesian crossbred dairy cows rearing under intensive management system. Heat stress in dairy cows is caused by a combination of environmental factors i.e. temperature, relative humidity, solar radiation and air movement, etc. Grading-up of local cattle by temperate breeds for greater performance results to increase the sensitivity to heat stress. The trial was conducted during hot (May-July) and cool period (December-February) on a total of 12 crossbred dairy cows in early lactation period (first 60 days of lactation). The selected cows were divided into two groups namely as $\mathrm{G}_{1}$ (Holstein-Friesian $50 \% \times$ Local $50 \%$ ) and $\mathrm{G}_{2}$ (Holstein-Friesian $75 \% \times$ Local $25 \%$ ) and each group containing three cows of 3rd lactation in both periods of trail. Cows of each group were offered same quality and quantity of feed and reared in same management condition in both the trail periods. The mean average temperature humidity index (THI) of the stanchion barn were 70.83 0.535 and $83.87 \pm 0.375$ in cool and hot period, respectively. The differences of THI of cool and hot season was significant $(p<0.05)$. The average rectal temperature $\left({ }^{0} \mathrm{~F}\right)$ of $\mathrm{G}_{1}$ group was $101.51 \pm 0.027$ and $102.15 \pm 0.049$ in cool and hot period, respectively. On the other hand, the average rectal temperature $\left({ }^{0} \mathrm{~F}\right)$ of $\mathrm{G}_{2}$ group was $101.68 \pm 0.035$ and $102.5 \pm 0.052$ in cool and hot period, respectively. The differences of rectal temperature of both groups between cool and hot season were significant $(p<0.05)$. The average milk yield (Liter/day) of both groups was significantly $(p<0.05)$ higher in cool period $\left(14.92 \pm 0.019\right.$ and $19.54 \pm 0.116$ for $G_{1}$ and $G_{2}$ group, respectively) than in hot period ( $12.84 \pm 0.152$ and $15 \pm 0.137$ for $\mathrm{G}_{1}$ and $\mathrm{G}_{2}$ group, respectively). The milk yield of $\mathrm{G}_{2}$ group hampered more compare to $\mathrm{G}_{1}$ group due to higher THI during hot season. The milk fat, protein and lactose of both groups were significantly higher $(p<0.05)$ during lower THI period compare to higher THI period, while the higher values of minerals detected in higher THI period but the differences were not statistically significant $(p<0.05)$. From the result it is evident that the milk yield and composition are greatly affected by the heat stress during early lactation period.
\end{abstract}

Key words: heat, stress, milk yield, composition, crossbred

Bangladesh Animal Husbandry Association. All rights reserved.

Bang. J. Anim. Sci. 2017. 46 (3): 192-197

\section{Introduction}

Bangladesh has a tropical monsoon-type climate, with a hot and rainy summer and a dry winter. Bangladesh has warm temperatures throughout the year, with relatively little variation from month to month. January tends to be the coolest month and May the warmest (http://www.discoverybangladesh). Heat stress for the dairy cow can be understood to indicate all high temperature-related forces that induce adjustments occurring from the sub-cellular to the whole animal level to help the cow avoid physiological dysfunction and for it to better fit its environment (Kadzere et al., 2002). Rectal temperature is an indicator of thermal balance and may be used to assess the adversity of the thermal environment. In severe cases of heat stress, the rectal temperature rise. The comfortable environmental temperature for dairy cattle ranges between 5 to $25^{\circ} \mathrm{C}$ which is also known as the thermal comfort zone. The effect is increased when the relative humidity is greater than $50 \%$. A rise of $1{ }^{\circ} \mathrm{C}$ or less is enough to reduce performance in most livestock species (McDowell et al., 1976). Feed intake in lactating cows begins to decline at the ambient temperatures of $25-26^{\circ} \mathrm{C}$ and drops more rapidly above $30{ }^{\circ} \mathrm{C}$. At $40^{\circ} \mathrm{C}$, dietary intake may decline by as much as $40 \%$ (National Research Council, 1989). Heat stress in high producing lactating dairy cows results in considerable reductions in roughage intake and rumination. The reduction in appetite under heat stress is a result of elevated

*Corresponding author: gkdebnathcvasu@yahoo.com 
body temperature and may be related to gut fill (Silanikove, 1992). It is accepted that heat stress is the major cause of lost production in dairy cattle in hostile regions. Some authors reported declines in the productions of milk and butter fat as a direct result of high environmental temperatures. This may be explained by the negative effects the heat stress has on the secretory function of the udder (Silanikove, 1992). Kadzereet al. (2002) found that milk production is reduced $15 \%$, accompanied by a $35 \%$ decrease in the efficiency of energy utilization for productive purposes, when a lactating Holstein cow is transferred from an air temperature of 18 to $30^{\circ} \mathrm{C}$. Milk fat, solids-notfat, and milk protein percentage decreased 39.7, 18.9 and $16.9 \%$ respectively. They also suggested that under heat stress metabolism is reduced, which is associated with reduced thyroid hormone secretion and gut motility, resulting in increased gut fill. Plasma growth hormone concentration and secretion rate declines with hot temperature $\left(35^{\circ} \mathrm{C}\right)$. Ruminal $\mathrm{pH}$ is typically lower in heat stressed cattle. The present study was undertaken to know the effect of heat stress on milk yield and gross composition of common Holstein Friesian crossbred cows during early lactation.

\section{Materials and Methods}

The trial was conducted during cool (December/2013- February/2014) and hot period (May/2014-July/2014), at Liza Dairy Farm in Chittagong, Bangladesh on a total of 12 crossbred dairy cows of Holstein-Friesian(H) $50 \%$ $\times \operatorname{Local}(\mathrm{L}) \quad 50 \%$ and $\mathrm{H} 75 \% \times \mathrm{L} 25 \%$ in early lactation period (first 60 days of lactation). The genetic composition, number of lactation, milk yield records in previous lactation and month of calving were the main criterion to select dairy cows. The selected cows were divided into two groups as $\mathrm{G}_{1}(\mathrm{H} 50 \% \times \mathrm{L} 50 \%)$ and $\mathrm{G}_{2}(\mathrm{H} 75 \% \times$ $L 25 \%$ ) and each group containing three cows of 3rd lactation in each period of trail. Cows were milked two times daily by hand milking (morning and evening) and recorded every day in the course of trial period in both seasons. The nutritional compositions of feedstuffs were analyzed in Poultry Research and Training Centre at Chittagong Veterinary and Animal Sciences University (CVASU). A ration was formulated as per ARC (1990) for each group of cows and offered in both period of trail. Cows were fed two times a day with mixed concentrate rations (Table 2 and 3 ) and four times green grass and rice straw manually.

Table1. Composition of feedstuffs

\begin{tabular}{llcc}
\hline \multicolumn{1}{c}{ Ingredients } & DM (g/kg) & ME (MJ/ kg DM) & CP (g/ kg DM) \\
\hline Green grass & 240 & 9.0 & 90.0 \\
Rice straw & 900 & 6.0 & 30.0 \\
Rice polish & 910 & 12.0 & 120.0 \\
Wheat barn & 890 & 12.0 & 140.0 \\
Soybean meal & 888 & 9.0 & 400.0 \\
Broken Maize & 895 & 12.5 & 8.5 \\
Mung bean bran & 900 & 9.0 & 250.0 \\
Molasses & 720 & 11.0 & 25.0 \\
\hline
\end{tabular}


Table 2. Daily feedstuffs consumption per cow of $\mathrm{G}_{1}$ group

\begin{tabular}{lrrrr}
\hline Ingredients & Quantity(kg) & DM(kg) & ME (MJ) & CP(g) \\
\hline Green grass & 16 & 3.840 & 34.560 & 345.6 \\
Straw & 2 & 1.800 & 10.800 & 54.00 \\
Rice polish & 2 & 1.820 & 21.840 & 218.400 \\
Wheat barn & 1.5 & 1.335 & 16.020 & 186.900 \\
Soya meal & 0.375 & 0.333 & 2.997 & 133.200 \\
Broken Maize & 1.2 & 1.074 & 13.425 & 9.129 \\
Mung bean bran & 1.5 & 1.350 & 12.150 & 337.500 \\
Molasses & 0.75 & 0.540 & 5.940 & 13.500 \\
Total & 25.325 & 12.092 & 117.732 & 1298.229 \\
\hline
\end{tabular}

Table 3. Daily feedstuffs consumption per cow of $\mathrm{G}_{2}$ group

\begin{tabular}{lrrrr}
\hline Ingredients & Quantity(kg) & DM(kg) & ME (MJ) & CP(g) \\
\hline Green grass & 20.000 & 4.800 & 43.200 & 432 \\
Straw & 2.750 & 2.475 & 14.850 & 74.25 \\
Rice polish & 2.250 & 2.0475 & 24.570 & 245.700 \\
Wheat barn & 1.500 & 1.335 & 16.020 & 186.900 \\
Soya meal & 0.750 & 0.666 & 5.994 & 266.400 \\
Broken Maize & 1.500 & 1.3425 & 16.781 & 11.411 \\
Mung bean bran & 2.000 & 1.800 & 16.200 & 450.000 \\
Molasses & 1.000 & 0.720 & 7.920 & 18.000 \\
Total & 31.75 & 15.186 & 145.535 & 1684.661 \\
\hline
\end{tabular}

Milking was carried out twice (morning and evening) daily throughout the study period. Both groups of cows were kept in a same stanchion barn. The milk samples were taken for chemical analysis two times daily after milking using dipper and plunger for proper mixing, and chemical composition of milk was determined by using Lactostar (Model No.3510, Funke Gerber, Germany) in Dairy Science Laboratory, CVASU. The meteorological data were recorded three times daily ( $8.00 \mathrm{am}, 1.00 \mathrm{pm}$ and $5.00 \mathrm{pm}$ ) by (Model PH1000, Zeal, England) and daily average values used for calculating the THI. The digital thermo-hygrometers were placed inside the barn at the altitude equal to animal height. The THI was calculated by applying the following formula of Maderet al. (2006):

$\mathrm{THI}=0.8 \times \mathrm{ta}+\mathrm{RH} / 100 \times(\mathrm{ta}-14.3)+46.3$

Where, THI is the temperature humidity index, ta is the ambient temperature in ${ }^{\circ} \mathrm{C}$ and $\mathrm{RH}$ is the relative humidity (\%). The rectal temperature of each cow in both groups were recorded daily by clinical thermometer in the afternoon. The mean with standard error of each parameter (THI, rectal temperature, milk yield and milk composition) were analyzed by PROC GLM and PROC MIXED of SAS (2000). The general linear model for this analysis was as:

$Y_{i j k}=\mu+B_{i}+S_{j}+e_{i j k}$

where,

$\left.\left(G_{2}\right)\right\}$

$$
\begin{aligned}
& Y_{i j k}=\text { Parameter value } \\
& \mu=\text { Overall mean } \\
& B_{i}=\text { Effect of } i^{\text {th }} \text { genotype }\left\{i=1\left(G_{1}\right) \text { and } 2\right.
\end{aligned}
$$
(cool)\}

$S_{j}=$ Effect of $j^{\text {th }}$ season $\{j=1$ (hot) and 2

$\mathrm{e}_{\mathrm{ijk}}=$ Error term, distributed as $\mathrm{N}\left(0, \sigma^{2}\right)$ 


\section{Results and Discussion}

The average THI was $70.83 \pm 0.535$ and 83.87 \pm 0.375 in cool and hot seasons, respectively. The highest average THI was found in May $(84.49 \pm 0.558)$ and lowest in January (68.79 \pm $0.413)$. The difference of THI in hot and cool season was statistically significant $(p<0.05)$. The season average rectal temperature $\left({ }^{0} \mathrm{~F}\right)$ of $\mathrm{G}_{1}$ group was $101.61 \pm 0.025$ and $102.15 \pm 0.049$ in cool and hot seasons, respectively. The highest and lowest average rectal temperature $\left({ }^{0} \mathrm{~F}\right)$ of $\mathrm{G}_{1}$ group was 102.17 \pm 0.055 and101.65 \pm 0.025 in May and January respectively. The season average rectal temperature $\left({ }^{0} \mathrm{~F}\right)$ of $\mathrm{G}_{2}$ group were $101.68 \pm$ 0.035 and $102.5 \pm 0.052$ in cool and hot seasons, respectively. The highest and lowest average rectal temperature $\left({ }^{0} \mathrm{~F}\right)$ of $\mathrm{G}_{2}$ group was $102.70 \pm 0.054$ and $101.65 \pm 0.025$ in May and January, respectively. The differences of THI in hot and cool season in case of both groups were statistically significant $(p<0.005)$. The THI is an important indicator traditionally used for prediction of milk yield during summer in dairy developed countries. Bucklin et al. (1991) suggested that milk production will be reduced whenever THI exceeds a value of 72 . Result shows that less than 72 THI value (70.83 \pm 0.535$)$ was during cool season and above $72(83.87 \pm 0.375)$ in hot season. The higher THI in hot season was due to higher barn temperature and humidity. Reyad et al. (2016) was also found the higher THI value than 72 in Mymensingh district of Bangladesh. The best approach to conclude that cows are being affected by heat stress is to measure the rectal temperature. Normal body temperature of the cow is about $38.5^{\circ} \mathrm{C}\left(101.3^{\circ} \mathrm{F}\right)$ and a cow that has a rectal temperature of $39^{\circ} \mathrm{C}\left(102.2^{\circ} \mathrm{F}\right)$ or higher during the afternoon, and it is not sick, is possible to be heat stressed. Determining rectal temperature of cows in the afternoon can be a quick way to get a precise judgment of the degree of heat stress and the efficiency of any cooling system integrated into cow housing (West, 2003; Willmer et al., 2004). From the results it is evident that there was a positive relationship of rectal temperature of cows with THI. Table 4. also shows that cows containing more temperate blood ( $75 \%$ Holstein-Frisian) suffer more from heat stress that might be reason of comparatively higher rectal temperature $(102.5 \pm 0.052)$ of cows under $G_{2}$ group in May, June and July and the rectal temperature of the cows under $\mathrm{G}_{1}$ group also a bit higher (102.15 \pm 0.049$)$ in the same months than normal value. The rectal temperature indicates that the both groups of cows were not in heat stressed condition during December, January and February might be due to lower THI value.

The daily average milk yield (Liter /cow) of $\mathrm{G}_{1}$ group was $14.92 \pm 0.019$ and $12.84 \pm 0.152$ in cool and hot period respectively. On the other hand, the daily average milk yield (lit./cow) of $\mathrm{G}_{2}$ group was $19.54 \pm 0.116$ and $15 \pm 01.137$ in cool period and hot period respectively. The result shows that higher milk production was in lower THI period and lower milk production in higher THI period for both groups of cattle. Result also indicate that level of production declined more in $\mathrm{G}_{2}$ group during heat stressed period compare to $G_{1}$ group. The difference of milk production between cool and hot season was significant $(p<0.05)$. The high milk production was recorded in cool season might be due to lower THI during December to February. This result agrees with the findings of Brown-Brandl et al. (2003) who found that milk production was clearly related to changes in $\mathrm{THI}$ and marked declines occur around 76-78 mean THI in case of temperate dairy breeds. A decrease in milk yield was $0.26 \mathrm{~kg} /$ day for each increase in THI. They also stated that all the adverse effects of the dangerous category are present in the emergency category at THI values of 82 and above. Wheelock et al. (2010) mentioned that dairy cows automatically will reduce their feed intake during period of heat stress, and this reduction could increase as weather becomes hotter. Typically, early lactation and high producing cows are more directly and severely affected than late lactation or low producing cows. The reduction in nutrient intake has been identified as a major cause of decline milk synthesis because this cause associated to a negative energy balance state, regardless of the stage of lactation but under heat stress conditions. In the present study the THI value was higher than 82 in all months during hot season that might be reason of drastic lowered milk production during May, June and July. Results also indicate that declining the milk yield was more in group $G_{2}$ than group $G_{1}$ during heat stressed period. Since the cows belongs to $G_{2}$ group contained less tropical blood that might be cause of higher heat stress and as a consequence of comparatively lower milk yield compare to higher tropical blood containing $\mathrm{G}_{1}$ group. The average protein $\%$ of $\mathrm{G}_{1}$ group was $3.43 \pm 0.002$ and $3.26 \pm 0.005$ and $G_{2}$ group $3.34 \pm 0.007$ and $3.19 \pm 0.008$ in cool and hot season respectively. 


\section{Heat stress on cows}

Table 4. Production performance of two different genotype groups in hot and cool period

\begin{tabular}{|c|c|c|c|c|c|c|c|c|c|c|c|c|c|c|c|c|c|c|}
\hline \multirow[b]{3}{*}{ Traits } & \multicolumn{9}{|c|}{$G_{1}(H 50 \% \times L 50 \%)$} & \multicolumn{9}{|c|}{$G_{2}(H 75 \% \times L 25 \%)$} \\
\hline & \multicolumn{4}{|c|}{$\begin{array}{c}\text { Non heat stress } \\
\text { months }\end{array}$} & \multicolumn{5}{|c|}{ Heat stress months } & \multicolumn{4}{|c|}{$\begin{array}{c}\text { Non heat stress } \\
\text { months }\end{array}$} & \multicolumn{5}{|c|}{ Heat stress months } \\
\hline & $\begin{array}{l}\text { De } \\
\text { C. }\end{array}$ & $\begin{array}{c}\text { Jan } \\
\text { uar } \\
y\end{array}$ & $\begin{array}{c}\text { Feb } \\
.\end{array}$ & $\begin{array}{c}\text { Mean } \\
\text { aver } \\
\text { age }\end{array}$ & $\begin{array}{c}\mathrm{Ma} \\
\mathrm{y}\end{array}$ & $\begin{array}{c}\text { Jun } \\
\mathrm{e}\end{array}$ & July & $\begin{array}{c}\text { Me } \\
\text { an } \\
\text { ave } \\
\text { rag } \\
\text { e }\end{array}$ & $\begin{array}{c}\text { Le } \\
\text { ve } \\
\text { I } \\
\text { of } \\
\text { si } \\
\text { gn }\end{array}$ & $\begin{array}{c}\text { Dec } \\
.\end{array}$ & $\begin{array}{c}\text { Jan } \\
\text { uar } \\
y\end{array}$ & $\begin{array}{c}\text { Feb } \\
.\end{array}$ & $\begin{array}{c}\text { Me } \\
\text { an } \\
\text { ave } \\
\text { rag } \\
\mathrm{e}\end{array}$ & $\begin{array}{c}\mathrm{Ma} \\
\mathrm{y}\end{array}$ & $\begin{array}{c}\text { Jun } \\
\mathrm{e}\end{array}$ & July & $\begin{array}{c}\text { Me } \\
\text { an } \\
\text { ave } \\
\text { rag } \\
\mathrm{e}\end{array}$ & $\begin{array}{l}\text { Le } \\
\text { ve } \\
\text { l } \\
\text { of } \\
\text { si } \\
\text { gn }\end{array}$ \\
\hline $\begin{array}{l}\text { Milk } \\
\text { Yield } \\
\text { (Lit.) }\end{array}$ & $\begin{array}{l}14 \\
.0 \\
8 \\
\pm \\
0 . \\
01 \\
9\end{array}$ & $\begin{array}{l}15 . \\
58 \\
\pm \\
0.0 \\
66\end{array}$ & $\begin{array}{l}15 . \\
12 \\
\pm \\
0.0 \\
86\end{array}$ & $\begin{array}{l}14.9 \\
2^{b} \pm \\
0.01 \\
9\end{array}$ & $\begin{array}{l}12 . \\
98 \\
\pm \\
0.0 \\
98\end{array}$ & $\begin{array}{l}12 . \\
88 \\
\pm \\
0.1 \\
91\end{array}$ & $\begin{array}{l}12 . \\
67 \\
\pm \\
0.1 \\
67\end{array}$ & $\begin{array}{l}12 . \\
84^{a} \\
\pm \\
0.1 \\
52\end{array}$ & $\begin{array}{l}* \\
*\end{array}$ & $\begin{array}{l}19 . \\
02 \\
\pm \\
0.1 \\
28\end{array}$ & $\begin{array}{l}20 . \\
22 \\
\pm \\
0.1 \\
00\end{array}$ & $\begin{array}{l}19 . \\
40 \\
\pm \\
0.1 \\
22\end{array}$ & $\begin{array}{l}19 . \\
54^{\mathrm{b}} \\
\pm \\
0.1 \\
16\end{array}$ & $\begin{array}{l}15 . \\
32 \\
\pm \\
0.1 \\
47\end{array}$ & $\begin{array}{l}14 . \\
79 \\
\pm \\
0.1 \\
47\end{array}$ & $\begin{array}{l}14 . \\
91 \\
\pm \\
0.1 \\
17\end{array}$ & $\begin{array}{l}15 . \\
01^{a} \\
\pm \\
0.1 \\
37\end{array}$ & $\begin{array}{l}* \\
*\end{array}$ \\
\hline $\begin{array}{l}\text { Milk } \\
\text { Fat( } \\
\%)\end{array}$ & $\begin{array}{l}4 . \\
22 \\
\pm \\
0 . \\
10 \\
9\end{array}$ & $\begin{array}{l}4.2 \\
6 \pm \\
0.0 \\
66\end{array}$ & $\begin{array}{l}4.2 \\
5 \pm \\
0.0 \\
82\end{array}$ & $\begin{array}{l}4.24^{\mathrm{b}} \\
\pm \\
0.08 \\
5\end{array}$ & $\begin{array}{l}3.7 \\
6 \pm \\
0.1 \\
64\end{array}$ & $\begin{array}{l}3.8 \\
5 \pm \\
0.1 \\
91\end{array}$ & $\begin{array}{l}3.8 \\
9 \pm \\
0.0 \\
98\end{array}$ & $\begin{array}{l}3.8 \\
3^{a} \pm \\
0.1 \\
51\end{array}$ & $\begin{array}{l}* \\
*\end{array}$ & $\begin{array}{l}3.6 \\
0 \pm \\
0.0 \\
06\end{array}$ & $\begin{array}{l}3.6 \\
8 \pm \\
0.0 \\
07\end{array}$ & $\begin{array}{l}3.6 \\
0 \pm \\
0.0 \\
06\end{array}$ & $\begin{array}{l}3.6 \\
3^{b} \pm \\
0.0 \\
06\end{array}$ & $\begin{array}{l}3.3 \\
5 \pm \\
0.0 \\
14\end{array}$ & $\begin{array}{l}3.3 \\
4 \pm \\
0.0 \\
09\end{array}$ & $\begin{array}{l}3.4 \\
0 \pm \\
0.0 \\
10\end{array}$ & $\begin{array}{l}3.3 \\
6^{a} \pm \\
0.0 \\
11\end{array}$ & $\begin{array}{l}* \\
*\end{array}$ \\
\hline $\begin{array}{l}\text { Lacto } \\
\text { se } \\
(\%)\end{array}$ & $\begin{array}{l}4 . \\
54 \\
\pm \\
0 . \\
00 \\
5\end{array}$ & $\begin{array}{l}4.5 \\
3 \pm \\
0.0 \\
06\end{array}$ & $\begin{array}{l}4.5 \\
4 \pm \\
0.0 \\
06\end{array}$ & $\begin{array}{l}4.53^{b} \\
\pm \\
0.00 \\
5\end{array}$ & $\begin{array}{l}4.5 \\
1 \pm \\
0.0 \\
08\end{array}$ & $\begin{array}{l}4.5 \\
0 \pm \\
0.0 \\
07\end{array}$ & $\begin{array}{l}4.5 \\
0 \pm \\
0.0 \\
06\end{array}$ & $\begin{array}{l}4.5 \\
0^{\mathrm{a}} \pm \\
0.0 \\
07\end{array}$ & $\begin{array}{l}\mathrm{N} \\
\mathrm{S}\end{array}$ & $\begin{array}{l}4.5 \\
2 \pm \\
0.0 \\
06\end{array}$ & $\begin{array}{l}4.5 \\
2 \pm \\
0.0 \\
14\end{array}$ & $\begin{array}{l}4.5 \\
3 \pm \\
0.0 \\
07\end{array}$ & $\begin{array}{l}4.5 \\
3^{b} \pm \\
0.0 \\
05\end{array}$ & $\begin{array}{l}4.4 \\
5 \pm \\
0.0 \\
08\end{array}$ & $\begin{array}{l}4.4 \\
5 \pm \\
0.0 \\
07\end{array}$ & $\begin{array}{l}4.4 \\
0 \pm \\
0.0 \\
08\end{array}$ & $\begin{array}{l}4.4 \\
3^{a} \pm \\
0.0 \\
08\end{array}$ & $\begin{array}{l}* \\
*\end{array}$ \\
\hline $\begin{array}{l}\text { Miner } \\
\text { als } \\
(\%)\end{array}$ & $\begin{array}{l}0 . \\
70 \\
\pm \\
0 . \\
00 \\
2\end{array}$ & $\begin{array}{l}0.6 \\
9 \pm \\
0.0 \\
03\end{array}$ & $\begin{array}{l}0.6 \\
9 \pm \\
0.0 \\
04\end{array}$ & $\begin{array}{l}0.69^{a} \\
\pm \\
0.00 \\
3\end{array}$ & $\begin{array}{l}0.6 \\
9 \pm \\
0.0 \\
04\end{array}$ & $\begin{array}{l}0.7 \\
1 \pm \\
0.0 \\
02\end{array}$ & $\begin{array}{l}0.7 \\
0 \pm \\
0.0 \\
04\end{array}$ & $\begin{array}{l}0.7 \\
b_{ \pm} \\
0.0 \\
03\end{array}$ & $\begin{array}{l}\mathrm{N} \\
\mathrm{S}\end{array}$ & $\begin{array}{l}0.6 \\
7 \pm \\
0.0 \\
06\end{array}$ & $\begin{array}{l}0.6 \\
7 \pm \\
0.0 \\
14\end{array}$ & $\begin{array}{l}0.6 \\
7 \pm \\
0.0 \\
07\end{array}$ & $\begin{array}{l}0.6 \\
7^{a} \pm \\
0.0 \\
09\end{array}$ & $\begin{array}{l}0.7 \\
1 \pm \\
0.0 \\
08\end{array}$ & $\begin{array}{l}0.7 \\
1 \pm \\
0.0 \\
07\end{array}$ & $\begin{array}{l}0.7 \\
1 \pm \\
0.0 \\
07\end{array}$ & $\begin{array}{l}0.7 \\
1^{b} \pm \\
0.0 \\
07\end{array}$ & $\begin{array}{l}N \\
S\end{array}$ \\
\hline
\end{tabular}

$* * \mathrm{p}<0.05,{ }^{\mathrm{a}}=$ lower value, ${ }^{\mathrm{b}}=$ higher value

The result indicates that higher $(3.43 \pm 0.002$ and $3.34 \pm 0.007)$ protein $\%$ was in lower THI period and lower (3.26 0.005 and $3.19 \pm 0.008$ ) protein $\%$ in higher THI period for both groups of cattle. The difference of protein production between cool and hot season was significant $(p<0.05)$. The differences of protein $\%$ in milk in two seasons might be due to heat stress. The results regarding milk protein is agreed with the findings of Zheng et al. (2009) who reported that heat stress significantly reduces the production of milk, percentage of milk fat and proteins. The average lactose percentage of $G_{1}$ group was
$4.53 \pm 0.005$ and $4.50 \pm 0.007$ in cool and hot period respectively. On the other hand, the average lactose percentage of $\mathrm{G}_{2}$ group was $4.53 \pm 0.005$ and $4.43 \pm 0.008$ in cool and hot season respectively. Result indicates that higher $(4.53 \pm 0.005$ and $4.53 \pm 0.005)$ lactose $\%$ was in

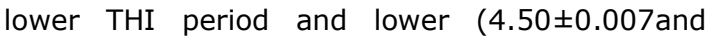
$4.50 \pm 0.007)$ in higher THI period for both groups of cattle. The differences of lactose \% between cool and hot season was significant $(p<0.05)$. Result indicates that lactose percentage was higher in lower THI period than higher THI period for both groups of cattle. This lowering content of 
lactose $\%$ in milk during May, June and July might be due to heat stress. The similar result was also obtained byJoksimovic-Tordorovic et al. (2011) who found that values for percentage of lactose varied slightly in spring $(4.45 \pm 0.54 \%)$ versus in summer $(4.03 \pm 0.24 \%)$ period.

The average minerals $\%$ of $\mathrm{G}_{1}$ group was $0.69 \pm$ 0.003 and $0.70 \pm 0.003$ in cool and hot period respectively. On the other hand, the mean average minerals percentage of $\mathrm{G}_{2}$ group was $0.67 \pm 0.009$ and $0.71 \pm 0.007$ in cool and hot season respectively. Result indicates that higher $(0.7 \pm 0.003$ and $0.71 \pm 0.007)$ minerals $\%$ was in higher THI period and lower $(0.69 \pm 0.003$ and $0.67 \pm 0.009$ ) in lower THI period for both groups of cattle. The differences in minerals content of milk between cool and hot season were not significant $(p<0.05)$ in both group. The difference of minerals $\%$ in milk in two seasons might be due to difference in climatic temperature and humidity and less feed intake during hot season. This finding was different from the result of Reyad et al. (2016) who got higher minerals\% in milk of Holstein Friesian crossbred cows during lower THI period and lower minerals $\%$ in higher THI period. Higher minerals content in milk during higher THI period might be due to declining the milk yield and increasing the concentration of minerals in milk as a consequence of heat stress.

\section{Acknowledgements}

The authors would like to thank the University Grants Commission, Bangladesh for providing financial support to conduct this research. The authors are grateful to the Liza dairy farm authority for their active cooperation.

\section{Conclusion}

Milk production of cows is influenced by environmental factors, especially high temperature and humidity during summer. The milk composition especially fat and protein are significantly affected in the period of hot environment. Since, high yielding cattle like Holstein-Friesian and Jersey are included in national cattle breeding policy of Bangladesh, the level of crossing with local cattle has been increasing day by day those progeny are very sensitive to heat stress. Only an intensive management can reduce the influence of heat stress on the quantity of milk production and profitability.

\section{References}

ARC (1990). Agricultural Research Council The Nutrient Requirement of Ruminant Livestock. Commonwealth Agricultural Bureau, London.

Brown-Brandl TM, JA Nienaber, RA Eigenberg, HC Freetly and GL Hahn (2003). Thermoregulatory responses of feeder cattle. Journal of Thermal Biology 28:149-157. http://www.discoverybangladesh: Climate of Bangladesh.

Joksimovic-Todorovic M, V Davidovic, S Hristov and B Stankovic (2011). Effect of Heat Stress on Milk production in Dairy Cows. Biotechnology in Animal Husbandry 27 (3): 1017-1023.

Kadzere CT, MR Murphy, N Silanikove and E Maltz (2002). Heat stress in lactating dairy cows: a review. Livestock Production Science 77: 5991.

Mader TL, MS Davis and T Brown-Brandl (2006). Environmental factors influencing heat stress in feedlot cattle. Journal of Animal Science 84: 712-719.

McDowell RE, NW Hooven and JK Camoens (1976). Effects of climate on performance of Holsteins in first lactation. Journal of Dairy Science 59:965-973.

NRC (1989). Nutrient Requirements of Dairy Cattle. National Research Council. National Academy Press, Washington, USA.

Reyad AM, HAM Sarker, EM Uddin, R Habib and UHM Rashid (2016). Effect of heat stress on milk production and its composition of Holstein Friesian crossbred dairy cows. Asian Journal of Medicine and Biological Research 2(2):190-195.

Silanikove N (1992). Effects of water scarcity and hot environment on appetite and digestion in ruminants: a review. Livestock Production Science 30:175-194.

West JW (2003). Effects of Heat-Stress on Production in Dairy Cattle. Journal of Dairy Science 86(6):2131-2144.

Wheelock JB, RP Rhoads, MJ VanBaale, SR Sanders and LH Baumgard (2010). Effect of heat stress on energetic metabolism in lactating Holstein cows. Journal of Dairy Science 93(2): 644-655.

Willmer P, G Stone and I Johnston (2004). Temperature and Its Effects, In Environmental Physiology of Animals. 2nd Edn, Wiley-Blackwell. West Sussex, United Kingdom, P. 182-245.

Zheng Chenh M and G Zhi-Cheng (2009). Effects of heat stress on milk performance and fatty acids in milk fat of Holstein dairy cows. Journal of China Dairy Industry 37(9):17-19. 